\title{
Nutritional Value of a Mushroom Fortified Maize Porridge for Complementary Feeding in Siaya County Kenya
}

\author{
Felix O Ondiek, Peter M Chege*, and Ann W Munyaka \\ Department of Food, Nutrition and Dietetics, Kenyatta University Kenya, Nairobi, Kenya
}

*Corresponding author: Peter M Chege, Department of Food, Nutrition and Dietetics, Kenyatta University, Kenya, E-mail: chegepeterm@gmail. com

Received: 02 Aug, 2019 | Accepted: 27 Aug, 2019 | Published: 03 Sep, 2019

Citation: Ondiek FO, Chege PM, Munyaka AW (2019) Nutritional Value of a Mushroom Fortified Maize Porridge for Complementary Feeding in Siaya County Kenya. Nutr Food Technol Open Access 5(2): dx.doi.org/10.16966/2470-6086.160

Copyright: (C) 2019 Ondiek FO, et al. This is an open-access article distributed under the terms of the Creative Commons Attribution License, which permits unrestricted use, distribution, and reproduction in any medium, provided the original author and source are credited.

\begin{abstract}
The overall objective of the study was to develop a fortified complementary porridge formulation based on maize and mushroom flours that would enhance IYCN in Siaya County, Kenya. The study assumed a single factor completely randomized experimental research design. Standard and validated procedures were used for nutrient analysis of samples; determinations were done in triplicates and means computed. Data was analyzed using SPSS Version 17. Independent $t$-test was used to compare mean values of samples at $p$ value $<0.05$ significance level. The results show significant mean compositional differences between fortified porridge and control porridge. Fortified porridge had significantly higher content of proteins, Iron, Zinc, Thiamine, Riboflavin, Niacin and folate compare to control porridge $(p<0.05)$. Control porridge had higher energy value than fortified porridge but the difference was not significant. The fortified porridge formulation had the capacity to enhance nutritional adequacy of infants and young children diet. The study recommends that mushroom be considered as a component in formulation of complimentary porridge flours.
\end{abstract}

Keywords: Nutritional value; Mushroom; Fortification; Maize porridge; Complementary feeding

\section{Introduction}

Malnutrition in childhood is an issue of public health concern globally and particularly in developing world [1]. Early nutrition is critical as it provides a strong foundation for a child's future health [2]. The contribution of malnutrition in the etiology of many infant and young child morbidities is widely acknowledged [3-5]. Malnutrition is implicated in an estimated $45 \%$ of mortalities in children under the age of five globally [6]. Research has established that the complementary feeding period is a most critical stage of development because of the continued rapid growth and many changes that occur which have serious implications on the child's health and development throughout the lifecycle [3]. Deficiencies of energy and essential nutrients during this period, if not corrected could result in irreversible lifetime consequences on a child's health and capabilities [7].

One of the major contributing factors of the wide-spread problems of malnutrition is the use of the starchy staple foods including cereal-based foods or starchy roots and tubers, commonly characterized by low protein and micronutrients content, as the basis for complementary foods. Furthermore, they are often prepared as thin gruels, which further lower their nutrient and energy density [8]. Children in the complementary feeding period (6 to 23 months age) have high nutritional needs to support rapid growth and development, which compounded with the challenge of limited gastric capacities, underscores the need for complementary foods to be high in both nutrient density and energy density. Unfortunately, the opposite is often the case for many children across the world and particularly many developing countries [9].

In developing countries, iron, zinc and vitamin A are generally the most problematic nutrients during the period of complementary feeding, largely because their low concentrations in human milk relative to the infant's needs [7,10]. Furthermore, other nutrients including Vitamin B complex may also be low depending on the types of foods consumed [11]. Diets that are predominantly based on grains and legumes are of particular concern with regard to the amount of bioavailable iron and zinc provided. This is because these foods are usually high in phytate, which binds these minerals and limits their absorption in the GIT [12,7].

The need to explore underutilized foods in a bid to overcome nutritional problems in various populations has been underscored [13]. Currently, the use of local food resources especially nonconventional foods with high nutritional value for infant and young children formulations is being strongly advocated [4]. Mushrooms represent a typical example of such crops with high nutritional and 
economic potential, but which largely remains underutilized and/or neglected [14]. Mushroom production and utilization in Kenya remain low due to lack of adequate information on their nutritional value as well as lack of appropriate post-harvest technologies for overcoming shelf life constraints as well as for value addition to enhance markets $[15,16]$. This study sought to determine the nutritional value of a mushroom-fortified maize porridge intended for complementary feeding as a means to enhance IYCN among the vulnerable populations in Siaya County, Kenya.

\section{Materials and Methods}

One batch of fresh oyster mushrooms (30Kgs) was sourced from the Jomo Kenyatta University of Agriculture and Technology Enterprises Section (JKUATES), quality sorted according to East African Standards Specification for Fresh mushrooms EAS56:2010 [17] and cleaned to remove any soil particles, then blanched by placing mushroom samples in a square piece of cotton cloth and tying well before suspending them in hot steam at $88^{\circ} \mathrm{C}$ for $1 \mathrm{~min}$. This was to inactivate the enzymes which have been found to influence content and native profile of some vitamins [18]. The blanched mushrooms were then solar-dried for two days before milling into flour.

One batch of dry shelled maize (30Kgs) was purchased from the local markets in Siaya and ferried to Nairobi. The maize was quality sorted according to East African Standards Specification for Maize grains EAS 2:2013 [19], then washed and soaked for two days before sun-drying to a stable moisture content of $10.74 \%$ as determined by oven drying followed by whole milling into flour. Portions of flour samples (500g each) was weighed and packed in airtight polythene bags, using a plastic sealing machine, and stored away from light at $-20^{\circ} \mathrm{C}$ for use as required. Nutrient analysis was conducted on raw flour samples and on two porridge samples i.e. plain maize four porridge (control) and composite (80:20-maize to mushroom flour) porridge. The $80: 20$ porridge formulation was selected after a sensory procedure described in a related publication.

A standard recipe was followed during the preparation of all the porridge samples: $100 \mathrm{~g}$ of flour was weighed into a sufuria (sauce pan) followed by addition of $1000 \mathrm{ml}$ of clean water and stirring to form a homogenous slurry. The slurry was cooked in medium heat with continuous stirring for 10 minutes into a thick gruel and allowed to cool to room temperature and then stored under deep freezing at $-20^{\circ} \mathrm{C}$ for laboratory analysis. Chemical analysis of the porridge samples was conducted in a span of three weeks from the date of preparation.

Proximate (total carbohydrates, crude protein, crude fat and crude ash) and mineral composition of samples were determined according to official methods: Moisture and ash were determined by the hot-air circulating oven and through incineration in a muffle furnace, respectively. Crude protein was determined by the microKjeldahl method and its content was obtained by multiplying the corresponding total nitrogen content by a factor of 6.25 and 4.38 for maize and mushroom proteins, respectively [20]. Total carbohydrate was determined by difference whereas energy was calculated using the Atwater's calorie conversion factors: $4 \mathrm{kcal} / \mathrm{g}$ for crude protein, $9 \mathrm{kcal} / \mathrm{g}$ for crude fat and $4 \mathrm{kcal} / \mathrm{g}$ for available carbohydrate [21]. Iron and zinc were determined using atomic absorption spectrophotometer (Shimadzu AA-6200Series, Japan) while the vitamins were determined according to the modified Reverse Phase-HPLC procedure with dual (UV and Fluorescence) detection as described by Ekinci R, et al. [22].

Data was analyzed using SPSS statistical computer software version 17.0 and presented in form of tables. All analytical determinations were carried out in triplicates and the mean values calculated. Descriptive statistics: means and percentages were used to describe nutrient content of samples: The independent t-test was used to compare mean nutrient values between samples differences, were tested at $95 \%$ confidence levels $(\mathrm{p}<0.05)$, in the dependent variable, between the control and fortified flour porridge samples.

\section{Results}

The results for Chemical analysis of raw flour samples are presented in (Tables 1,2). Results for proximate analysis showed that mushroom flour had significantly higher contents of crude ash and crude protein $(\mathrm{p}<0.001)$ while the maize flour had significantly higher energy value $(\mathrm{p}=0.001)$. The moisture contents at which of the two samples were analysed were not significantly different $(\mathrm{p}=0.772)$.

\section{Micronutrient content}

As shown in table 2, mushroom flour had significantly higher contents of all the micronutrients than maize flour $(\mathrm{p}<0.05)$.

\section{Nutrient content of porridge samples}

A fortified porridge flour was prepared by mixing maize and mushroom flour in the ratio of 80:20 maize to mushroom flour. The fortified flour porridge was similarly analysed against the control porridge (which was prepared from $100 \%$ maize flour) for proximate composition, iron, zinc, thiamine, riboflavin, niacin and folate in the second phase of nutrient analysis and the results were obtained as presented in tables 3,4 . The fortified porridge had significantly higher content of proteins $(\mathrm{p}<0.001)$ and crude ash $(\mathrm{p}<0.001)$. There was no significant difference in energy value between the two porridge samples $(\mathrm{p}=0.182)$.

Table 1: Proximate content of raw flour samples (g/100g) fresh weight basis.

\begin{tabular}{|l|c|c|c|}
\hline \multirow{1}{*}{ Nutrient } & Maize flour & Mushroom flour & P value \\
\cline { 3 - 4 } & & & (t-test) \\
\hline Moisture content & $10.74 \pm 0.4$ & $10.65 \pm 0.37$ & 0.772 \\
\hline Energy value* & $367.56 \pm 0.83$ & $341.92 \pm 4.89$ & 0.001 \\
\hline Total carbohydrates & $75.31 \pm 0.57$ & $50.13 \pm 1.69$ & $<0.001$ \\
\hline Crude proteins & $9.91 \pm 0.22$ & $28.69 \pm 0.96$ & $<0.001$ \\
\hline Crude fat & $3.0 \pm 0.13$ & $2.96 \pm 0.90$ & 0.989 \\
\hline Crude ash & $1.08 \pm 0.23$ & $7.58 \pm 0.26$ & $<0.001$ \\
\hline
\end{tabular}

NB:

1. Values are means \pm standard deviation.

2. *Values are presented in Kcal

Table 2: Micronutrient content of raw flour samples (mg/100g) fresh weight basis.

\begin{tabular}{|l|c|c|c|}
\hline \multicolumn{1}{|c|}{ Nutrient } & Maize flour & Mushroom flour & P value \\
\hline Iron & $2.76 \pm 0.18$ & $6.35 \pm 0.23$ & $<0.001$ \\
\hline Zinc & $1.55 \pm 0.06$ & $4.73 \pm 0.40$ & 0.004 \\
\hline Thiamine & $0.44 \pm 0.01$ & $1.73 \pm 0.48$ & 0.01 \\
\hline Riboflavin & $0.18 \pm 0.2$ & $1.14 \pm 0.05$ & $<0.001$ \\
\hline Niacin & $3.54 \pm 0.13$ & $15.80 \pm 1.90$ & $<0.001$ \\
\hline Folates & $20.12 \pm 0.52^{*}$ & $244.96 \pm 10.85^{*}$ & 0.001 \\
\hline
\end{tabular}

\section{NB:}

1. Values are means \pm standard deviation.

2. Values with superscript* are reported in $\mu \mathrm{g} / 100 \mathrm{mg}$.

3. Mushroom flour had significantly higher content of all the micronutrients than the maize flour. 
Table 3: Proximate composition of porridge samples (g/ 100g) fresh weight basis.

\begin{tabular}{|l|c|c|c|}
\hline \multirow{2}{*}{\multicolumn{1}{|c|}{ Nutrient }} & Control porridge & Fortified porridge & P value \\
\cline { 2 - 4 } & $(100: 0)$ & $(80: 20)$ & (t-test) \\
\hline Moisture content & $87.12 \pm 0.35$ & $87.17 \pm 0.17$ & 0.134 \\
\hline Energy value & $51.46 \pm 2.0 *$ & $49.18 \pm 0.42^{*}$ & 0.182 \\
\hline Total Carbohydrate & $11.99 \pm 0.65$ & $9.56 \pm 0.10$ & 0.021 \\
\hline Crude protein & $1.23 \pm 0.17$ & $2.25 \pm 0.04$ & $<0.001$ \\
\hline Crude fat & $0.23 \pm 0.06$ & $0.22 \pm 0.02$ & 0.637 \\
\hline Crude ash & $0.09 \pm 0.01$ & $0.97 \pm 0.08$ & $<0.001$ \\
\hline
\end{tabular}

NB:

1. Values are means \pm standard deviation.

2. Values with superscript* are presented in Kcal.

Table 4: Micronutrient content of porridge samples $(\mathrm{mg} / 100 \mathrm{~g})$ fresh weight basis.

\begin{tabular}{|l|c|c|c|}
\hline Nutrient & Control porridge & Fortified porridge & P value \\
\hline Iron & $0.33 \pm 0.02$ & $0.80 \pm 0.03$ & $<0.001$ \\
\hline Zinc & $0.26 \pm 0.01$ & $0.39 \pm 0.01$ & $<0.001$ \\
\hline Thiamine & $0.05 \pm 0.00$ & $0.09 \pm 0.00$ & $<0.001$ \\
\hline Riboflavin & $0.03 \pm 0.00$ & $0.10 \pm 0.01$ & $<0.001$ \\
\hline Niacin & $0.38 \pm 0.02$ & $1.15 \pm 0.01$ & $<0.001$ \\
\hline Folate & $1.67 \pm 0.40^{*}$ & $9.31 \pm 1.01^{*}$ & $<0.001$ \\
\hline
\end{tabular}

NB:

1. Values are means \pm standard deviation.

2. Values with superscript* are reported in $\mu \mathrm{g} / 100 \mathrm{~g}$.

3. Fortified porridge significantly higher in all the micronutrients than the control porridge.

\section{Micronutrient content}

As shown in table 4, differences in micronutrient contents between the two porridge samples were highly significant (P-value $<0.001$ for all the micronutrients) with the fortified porridge having higher values.

\section{Fortified porridge and recommended nutrient intakes}

As shown in table 5 the results show that the fortified porridge can contribute significantly to the fulfillment of the daily nutrient requirements for children within the targeted age bracket (6-23 months).

\section{Sources}

1. Institute of Medicine. 1998. Dietary Reference Intakes for Thiamine, Riboflavin, Niacin, Vitamin B6, Folate, Vitamin B12, Pantothenic acid, Biotin and Choline. Washington, D.C.: National Academies Press.

2. Institute of Medicine (Ed.). (2005). Dietary reference intakes for energy, carbohydrate, fiber, fat, fatty acids, cholesterol, protein, and amino acids. Washington, D.C: National Academy Press.

3. Institute of Medicine (U.S.). (2002). DRI: Dietary reference intakes for vitamin $\mathrm{A}$, vitamin $\mathrm{K}$, arsenic, boron, chromium, copper, iodine, iron, manganese, molybdenum, nickel, silicon, vanadium, and zinc: a report of the Panel on Micronutrients. and the Standing Committee on the Scientific Evaluation of Dietary Reference Intakes, Food and Nutrition Board, Institute of Medicine.
Table 5: Percentage RDA fulfillment of various nutrients per $100 \mathrm{~g}$ of fortified porridge for children 6 months-3 years.

\begin{tabular}{|c|c|c|c|}
\hline & $\begin{array}{c}\text { Recommended } \\
\text { Nutrient } \\
\text { Intakes }^{\mathrm{a}}\end{array}$ & $\begin{array}{c}\text { Composition } \\
\text { of fortified } \\
\text { porridge/100g }\end{array}$ & $\begin{array}{c}\text { Contribution to } \\
\text { RNI (\%) }\end{array}$ \\
\hline \multicolumn{4}{|c|}{$1-3$ years } \\
\hline Energy (kcal) & 1300 & 49.18 & 3.78 \\
\hline Protein (g) & 16 & 2.25 & 14.06 \\
\hline Thiamine (mg) & 0.5 & 0.09 & 18.8 \\
\hline Riboflavin (mg) & 0.5 & 0.1 & 19 \\
\hline Niacin (mg NE) & 6 & 1.15 & 19.17 \\
\hline Folate ( $\mu \mathrm{g} /$ day) & 150 & 9.31 & 6.21 \\
\hline Iron (mg) & 7 & 0.8 & 11.43 \\
\hline Zinc (mg) & 3 & 0.39 & 13 \\
\hline \multicolumn{4}{|c|}{ 6-12 months } \\
\hline Energy (kcal) & 1300 & 49.18 & 3.78 \\
\hline Protein (g) & 10.6 & 2.25 & 21.23 \\
\hline Thiamine (mg) & $0.3^{*}$ & 0.09 & 30 \\
\hline Riboflavin (mg) & $0.4^{*}$ & 0.1 & 25 \\
\hline Niacin (mg NE) & $4.0^{*}$ & 1.15 & 28.75 \\
\hline Folate ( $\mu \mathrm{g} /$ day) & $80^{*}$ & 9.31 & 11.64 \\
\hline Iron (mg) & 11 & 0.8 & 7.27 \\
\hline Zinc (mg) & 3 & 0.39 & 13 \\
\hline
\end{tabular}

*Adequate intakes

\section{Discussion}

Current results show plainly that oyster mushrooms are superior than maize in nutrient content, with regard to the key nutrients which were under investigation including proteins, iron, zinc and vitamin B complex, and thus qualify for use in nutritional enrichment of complementary preparations where maize flour is the bulk ingredient. Current values for protein content of oyster mushrooms agree with those reported by other studies; by Bhattacharjya DK [23], by Ahmed M, et al. [24] and by Stamets P, et al. [25], who reported 27.30, 28.40 and $27.25 \mathrm{mg} / 100 \mathrm{~g}$, respectively at more or less similar moisture content. Regula J, et al., [26] and Okon OG, et al., [27] however, obtained lower values for proteins in mushrooms namely 15.7 and $10.21 \mathrm{mg} / 100 \mathrm{~g}$, respectively at a similar moisture content of $10.6 \%$. The protein content of mushrooms is reportedly affected by factors such as mushroom variety, stage of development, the part sampled, level of nitrogen available in the substrate and geographical location, i.e., where the mushroom are obtained. This study confirms mushrooms as a rich source of proteins as previously reported by other researches [26]. Mushrooms outcompetes many of non-animal sources of protein such as grains and vegetables. The protein content of mushrooms reportedly falls between that of vegetables and animal sources [28].

Results for iron corroborate those of a study by Regula J, et al. [26] (6.86mg/100), by Mallikarjuna SE, et al. [29] $(6.27 \mathrm{mg} / 100 \mathrm{~g})$ and by Li H, et al. [30] (7.1mg/100g). A good number of studies have also reported high contents of iron in mushroom flour in the range of 15-65mg/100g [24,31-33] while others have reported iron contents as low as lower iron content of $2.19 \mathrm{mg} / 100 \mathrm{~g}$ in mushroom flour. Current results for zinc content in mushroom flour reflect those of $\mathrm{Li} \mathrm{H}$, et al. [30] by Mallikarjuna SE, et al. [29] and by Poongkodi GK, et al. [33], who reported $4.2-5.5 \mathrm{mg} / 100 \mathrm{~g}, 5.06 \mathrm{mg} / 100 \mathrm{~g}$ and $4.89-6.51 \mathrm{mg} / 100 \mathrm{~g}$, respectively. Other authors have, reported relatively higher zinc 
contents ranging between 9 and $27.6 \mathrm{mg} / 100 \mathrm{~g}[23,31]$. The composition of mineral elements in mushrooms has been shown to be strongly affected by the chemical composition of the substrate or compost on which they are grown as well the species and size of samples [34].

The findings for both minerals in maize flour fall within the range, albeit slightly below, the values of 3.5 and $1.8 \mathrm{mg} / 100 \mathrm{~g}$ (reported in Tanzania Food Composition Tables) and 3.8 and $1.7 \mathrm{mg} / 100 \mathrm{~g}$ (reported in West African Food Composition Tables) for iron and zinc, respectively $[35,36]$. This study therefore, confirms the potential of mushrooms to address widespread mineral deficiencies across populations as reported in other work [37,38], particularly the essential minerals including Iron and Zinc whose deficiencies are common in developing countries. Mineral deficiencies (especially Fe, Zn) in the diet affect the health and the development of children and results in potentially life threatening complications [39].

Current results for thiamine fall within the range of 1.9 to $2.0 \mathrm{mg} / 100 \mathrm{~g}$ previously reported by $[31,32,40]$. However, [25] reported much lower content of thiamine in mushroom flour $(0.16 \mathrm{mg} / 100 \mathrm{~g})$.

Riboflavin content of mushroom flour obtained in the current study fall slightly below those reported by [25] and [31] whose values range between 1.9 and $2.4 \mathrm{mg} / 100 \mathrm{~g}$. Findings for Niacin content of mushroom flour for this study fall outside the range reported by most studies i.e., $30-108 \mathrm{mg} / 100 \mathrm{~g}[25,31]$. Only two studies i.e., Mattila P, et al. [32] and Wang $\mathrm{H}$, et al. [40] were identified that adequately reported the content of folate for mushroom flour. Their figures which ranged between 300 and $700 \mu \mathrm{g} / 100 \mathrm{~g}$ fall above the results of the current study.

Although the fortified porridge was lower in carbohydrate and fat content, this was compensated by its higher values in protein content so that the two porridge samples were not significantly different in energy value $(\mathrm{p}=0.182)$. Supplementation of maize flour with mushroom flour at $20 \%$ rate therefore, did not significantly compromise the energy value of the porridge. Energy density is a key consideration in foods meant for complementary feeding since children at this stage are in their critical growth period and are most vulnerable to Protein Energy Malnutrition (PEM) which is the most prevalent form of malnutrition worldwide [41].

Current findings for protein content of the control porridge are corroborated by the values (1.2\%) posted in the West African Food Composition Tables [35]. But fall above the values (0.8\%) posted in the Tanzanian food composition tables [36]. Proteins constitute an important nutritional component of complementary foods supplying essential amino acids (EAAs) as well as energy during times of energy deprivation. Adequate supply of dietary proteins is vital for maintaining cellular function and integrity as well as ensuring normal health and growth. Combined protein deficiency and low energy intake leads to PEM.

The findings for iron and zinc determination in control porridge agree with those reported in the TZFCTs $(0.33$ and $0.2 \mathrm{mg} / 100 \mathrm{~g}$ respectively. The WAFCTs has however, reported lower values $(0.04$ and $0.06 \mathrm{mg} / 100 \mathrm{~g}$ for iron and zinc, respectively).

Findings for riboflavin and niacin are within the statistical range of those reported in WAFCTs (0.02) and TZFCTs (0.4), respectively. However, higher thiamine content was obtained for maize porridge than reported in both the TZFCTs and the WAFCTs $(0.0$ and $0.01 \mathrm{mg} / 100 \mathrm{~g}$ respectively). Current values for folate content of maize porridge also fall between the values reported by the two composition tables $(1.0$ and $3.0 \mu \mathrm{g} / 100 \mathrm{~g})$.

\section{Conclusion}

The nutritional value of oyster mushrooms particularly their potential for use in the nutritional fortification of cereal based complementary foods in populations with low dietary diversity has been demonstrated by this study. Oyster mushrooms were found to be of superior nutrient density compared to maize flour. Porridge from the fortified flour had superior nutritional value compared to the unfortified maize flour porridge. The fortified porridge formulation had the capacity to enhance nutritional adequacy of infants and young children diet. The study recommends that mushroom be considered as a component in formulation of complimentary porridge flours.

\section{Ethical Approval}

Ethical clearance was obtained from Ethical Review Committee from Kenyatta University.

\section{Competing Interests}

The authors declare that they have no competing interests.

\section{Funding}

The research was funded by the researchers.

\section{Acknowledgement}

The authors would like to thank all participants in the research.

\section{References}

1. Webb P, Stordalen GA, Singh S, Wijesinha-Bettoni R, Shetty $P$, et al. (2018) Hunger and malnutrition in the $21^{\text {st }}$ century. BMJ: k2238.

2. World Health Organization (2014) Comprehensive Implementation Plan on Maternal Infant and Young Child Nutrition.

3. Black RE, Allen LH, Bhutta ZA, Caulfield LE, de Onis M, et al. (2008) Maternal and child under nutrition: Global and regional exposures and health consequences. The Lancet 371: 243-260.

4. Chadare FJ, Madode YE, Fanou-Fogny N, Kindossi JM, Ayosso JO, et al. (2018) Indigenous food ingredients for complementary food formulations to combat infant malnutrition in Benin: A review: Potential of indigenous foods in the formulation of infant foods. J Sci Food Agric 98: 439-455.

5. Tomkins A (2000) Malnutrition, morbidity and mortality in children and their mothers. Proc Nutr Soc 59: 135-146.

6. World Health Organization (2018) Malnutrition.

7. Dewey KG (2013) The Challenge of Meeting Nutrient Needs of Infants and Young Children during the Period of Complementary Feeding: An Evolutionary Perspective. J Nutr 143: 2050-2054.

8. Gibson R, Ferguson E, Lehrfeld J (1998) Complementary foods for infant feeding in developing countries: Their nutrient adequacy and improvement. Eur J Clin Nutr 52: 764-770.

9. Osendarp SJ, Broersen B, van Liere MJ, De-Regil LM, Bahirathan L, et al. (2016) Complementary Feeding Diets Made of Local Foods can be Optimized, but Additional Interventions will be Needed to Meet Iron and Zinc Requirements in 6-to 23-Month-Old Children in Low- and Middle-Income Countries. Food Nutr Bull 37: 544-570.

10. Raymond J, Kassim N, Rose JW, Agaba M (2017) Optimal formulations of local foods to achieve nutritional adequacy for 6-23-month-old rural Tanzanian children. Food Nutr Res 61: 1358035.

11. World Health Organization (2006) Guidelines on food fortification with micronutrients. World Health Organization, FAO, Geneva, Switzerland. 
12. Agbon CA, Onabanjo OO, Akinyemi CO (2011) Micronutrient adequacy of homemade complementary foods. Nutrition \& Food Science 41: 12-19.

13. FAO (1997) Preventing micronutrient malnutrition: A guide to foodbased dietary approaches. ILSI Press, International Life Sciences Institute, Washington, DC, USA.

14. Durst P, Bayasgalanbat N (2014) Promotion of underutilized indigenous food resources for food security and nutrition in Asia and the Pacific. Food and Agriculture Organization of the United Nationsergional Office for Asia and the Pacific Bangkok.

15. Afetsu JY (2014) Postharvest Losses in Oyster Mushroom (Pleurotus ostreatus) Produced in the Ho Municipality of the Volta Region of Ghana. Kwame Nkrumah University of Science and Technology, Ghana.

16. Bernas E, Jaworska G, Kmiecick W (2006) Storage and Processing of Edible Mushrooms. Acta Sci Pol Tech Aliment 5: 5-23.

17. East African Community (2010) EAS 56: 2010 East African Standard: Fresh mushrooms: Specification and grading. Second Edition, East African Community, Tanzania.

18. Munyaka AW, Makule EE, Oey I, Van Loey A, Hendrickx M (2010) Thermal Stability of I-Ascorbic Acid and Ascorbic Acid Oxidase in Broccoli (Brassica oleracea var. Italica). J Food Sci 75: C336-C340.

19. EAC (2013) Maize grains quality specifications EAS 2: 2013. East African Community, Arusha, Tanzania.

20. FAO/Government of Kenya (2018) Kenya Food Composition Tables 2018. Nairobi 254.

21. Atwater WO (1916) Principles of nutrition and nutritive value of food. US Department of Agriculture, Washington, USA.

22. Ekinci R, Kadakal C (2005) Determination of Seven Water-soluble Vitamins in Tarhana, a Traditional Turkish Cereal Food, by HighPerformance Liquid Chromatography. ACTA Chromatographica 15.

23. Bhattacharjya DK, Paul RK, Miah MN, Ahmed KU (2015) Comparative Study on Nutritional Composition of Oyster Mushroom (Pleurotus ostreatus Fr.) Cultivated on Different Sawdust Substrates. Biores Comm 1: 93-98.

24. Ahmed M, Abdullah N, Nuruddin MM (2016) Yield and Nutritional Composition of Oyster Mushrooms: An Alternative Nutritional Source for Rural People. Sains Malaysiana 45: 1609-1615.

25. Stamets $P$ (2005) Mycelium Running: How mushrooms Can Help Save the World. Potter/Ten Speed/Harmony/Rodale 356.

26. Regula J, Siwulski M (2007) Dried shiitake (Lentinulla edodes) and oyster (Pleurotus ostreatus) mushrooms as a good source of nutrient. Acta Sci Pol Technol Aliment 6: 135-142.
27. Okon OG, Okon U, Obongotdot N (2015) Proximate and Antinutrient Content of Pleurotus Ostreatus (Jacq.) P. Kumm Found in Akwa lbom State, Nigeria. Int J Res Rev 2: 217-222.

28. Kakon AJ, Choudhury MBK, Saha S (2012) Mushroom is an ideal food supplement. J Dhaka National Med Col Hos 18: 58-62.

29. Mallikarjuna SE, Ranjini A, Haware DJ, Vijayalakshmi MR, Shashirekha MN, et al. (2013) Mineral Composition of Four Edible Mushrooms. J Chem 2013: 1-5.

30. Li H, Zhang Z, Li M, Li X, Sun Z (2017) Yield, size, nutritional value, and antioxidant activity of oyster mushrooms grown on perilla stalks. Saudi J Biol Sci 24: 347-354.

31. Deepalakshmi K, Sankaran M (2014) Pleurotus ostreatus: An oyster mushroom with nutritional and medicinal properties. J Biochem Tech 5: 718-726.

32. Mattila P, Könkö K, Eurola M, Pihlava JM, Astola J, et al. (2001) Contents of Vitamins, Mineral Elements, and Some Phenolic Compounds in Cultivated Mushrooms. J Agric Food Chem 49: 23432348.

33. Poongkodi GK, Harithral Priya GP, Harithral Priya (2015) Nutrient Contents of Edible Mushrooms, Agaricusbisporus and Pleurotusostreatus. Int J Modern Chem Appl Sci 2: 78-86.

34. Bellettini MB, Fiorda FA, Maieves HA, Teixeira GL, Ávila S, et al. (2016) Factors affecting mushroom Pleurotus spp. Saudi J Biol Sci 26: 633-646.

35. FAO (2012) West African food composition table. Rome, Italy.

36. Lukmanji Z, Hertzmark E, Mlingi N, Assey V, Ndossi G, et al. (2008) Tanzania food composition tables. $1^{\text {st }}$ Edition, MUHAS, TFNC, HSPH, Dar es Salaam, Tanzania.

37. Stein AJ (2010) Global impacts of human mineral malnutrition. Plant and Soil 335: 133-154.

38. White P, Broadely MR (2009) Biofortification of crops with seven mineral elements often lacking in human diets-iron, zinc, copper, calcium, magnesium, selenium and iodine. New Phytol 182: 49-84.

39. FAO/WHO (2001) Human Vitamin and Mineral Requirements. Food and Agricultural Organization of the United Nations, WHO.

40. Wang H, Ng TB (2006) Ganodermin, an antifungal protein from fruiting bodies of the medicinal mushroom Ganoderma lucidum. Peptides 27: 27-30

41. AbeshuMA, Lelisa A, Geleta B (2016) Complementary Feeding: Review of Recommendations, Feeding Practices, and Adequacy of Homemade Complementary Food Preparations in Developing Countries-Lessons from Ethiopia. Front Nutr 3. 